\section{Classification and current treatment options of endo-perio lesions}

\section{Endo-perio lezyonların sınıflaması ve güncel tedavi seçenekleri}

\section{Dr. Gizem Ince Kuka}

Yeditepe University, Faculty of Dentistry, Department of Periodontology, İstanbul

\section{Dr. Güher Barut}

Yeditepe University, Faculty of Dentistry, Department of Endodontics, İstanbul

\section{Assoc. Prof. Hare Gürsoy}

Yeditepe University, Faculty of Dentistry, Department of Periodontology, İstanbul

Received: 12 September 2016

Accepted: 4 November 2016

DOI: 10.5505/yeditepe.2017.92485

\author{
Corresponding author: \\ Dr. Güher Barut \\ Yeditepe University, Faculty of Dentistry \\ Department of Endodontics \\ Bağdat Cad. No: 23834728 Göztepe/İstanbul \\ Tel: 02163636044-6464 \\ Email: guherbarut85@hotmail.com
}

\section{SUMMARY}

The root canal and periodontium are in a close relation with each other and cross infection between dental pulp tissue and periodontal ligament may occur by the anatomical structures and non-physiological pathways. Endo-perio lesions are challenging for the clinicians in terms of diagnosis and prognosis. It is important to understand the etiology of the lesions to determine the timing and ordering the treatment procedures. In some cases, endodontic or periodontal treatment is sufficient alone while secondary involvement of endodontic or periodontal lesions or true combined lesions are required more complicated treatment options. There is a lack of knowledge about the treatment protocols concerning endo-perio lesions therefore this review aims to highlight the current and advanced treatment strategies.

Key words: Classification, endo-perio lesion, combined lesions.

\section{ÖZET}

Diş ve çevre dokuları incelendiğinde, kök kanallarının ve periodonsiyumun birbiriyle yakın ilişki içinde olduğu belirlenmiştir. Pulpa dokusu ve periodontal ligament arasında anatomik yapılar ve fizyolojik olmayan yollar aracılığıyla enfeksiyon geçişleri olabilmektedir. Bunun sonucunda oluşan endo-perio lezyonlarının teşhisi ve prognozu klinisyenleri oldukça zorlamaktadır. Bu lezyonların etiyolojisinin anlaşılması, tedavi seçeneklerinin zamanlaması ve sıralaması açısından büyük önem taşımaktadır. Birçok vakada endodontik veya periodontal tedavi tek başına yeterli olurken, ikincil olarak endodontik veya periodontal lezyonlar eklendiğinde veya gerçek kombine lezyonların varlığında daha karmaşık tedavi seçeneklerine intiyaç duyulmaktadır. Endo-perio lezyonlarının tedavi protokolleri konusunda literatürde yeterli bilgi bulunmamakla birlikte, bu derlemenin amacı güncel ve ileri tedavi planlamalarına dikkat çekmektir.

Anahtar Kelimeler: Sınıflama, endo-perio lezyon, kombine lezyon.

\section{INTRODUCTION}

Endodontic and periodontal diseases are both polymicrobial anarebic infections. ${ }^{1}$ The term "endo-perio" lesion describes diseases due to inflammatory products found in varying degrees in both the periodontium and the pulpal tissues introduced by Simring and Goldberg in 1964. ${ }^{2}$ Etiologic factors mostly of bacterial origin via apical foramen, lateral and accessory canals and dentinal tubules as well as various non-physiological factors such as trauma, root resorptions, perforations, and dental malformations play an important role in the development and progression of such lesions. ${ }^{3}$

Pathways of Communication

\section{Anatomical Pathways}

1.1. Apical foramen

Apical foramina forms the major connection between the 
periodontium and dental pulp. ${ }^{1}$ Total disintegration of pulp due to periodontal disease is possible only if bacterial plaque biofilm involves the apical foramen and compromise the blood supply. Following the necrosis of the pulp, bacterial metabolites and enzymes reach the periodontium and initiate an inflammatory response. This

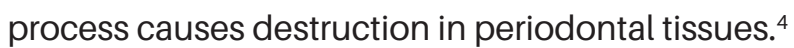

\subsection{Lateral and accessory canals}

Lateral canals are the lateral branches of the root canal, connecting the neurovascular system of the dental pulp with that of periodontal ligament. ${ }^{5}$ Currently, these ramifications are named as 'accessory canals'. During the early stages of tooth development these anastomoses are formed but may be obliterated or reduced with the completion of root formation. ${ }^{4}$ Majority of these canals are found in the apical part of the root and the furcation areas of multi-rooted and may be a possible route for microorganisms and their products. The presence of such ramifications can be diagnosed by localized thickening of periodontal ligament on the lateral root surface or with a lateral lesion. ${ }^{4,5}$

\subsection{Dentinal tubules}

Dentinal tubules are formed during odontogenesis with a shape of an inverted cone. The opening of these tunnels has the smallest dimension at the periphery while the largest at the pulp. ${ }^{1}$ Passage of microorganisms between the pulp and periodontal tissues is possible through these tubules in presence of denuded cement areas. ${ }^{2-4}$

\section{Non-Physiological Pathways}

latrogenic root canal perforations that result artificial communication may occur during dental treatments such as post preparation and endodontic treatment. Another artificial communication of periodontium and dental pulp is vertical root fractures caused by trauma, which can be seen in both vital and non-vital teeth. Root fractures are more common in teeth with endodontic treatment that are filled with lateral condensation technique. 1,4,6

\section{Classification of Endo-Perio Lesions}

The lesions caused by the close relationship of the pulp and periodontal diseases are classified according to the etiology and diagnosis of the lesion. ${ }^{7}$ The classification of the endo-perio lesions is essential for the proper treatment choice and predictable success of the treatment. Although many classifications were offered, ${ }^{8-12}$ generally accepted classification of the endo-perio lesions was introduced by Simon et al. ${ }^{7}$ Based on this classification, five types of endo-perio lesios exist (Figure 1).

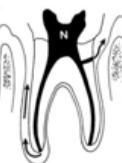

(a)

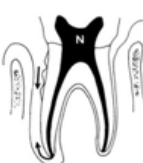

(b)

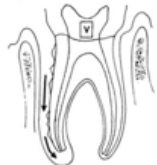

(c)

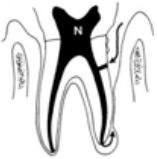

(d)

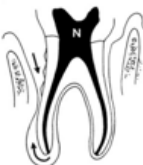

(e)
Figure 1: Classification of Endo-Perio Lesions (Modified from Simon et al.7)

(a) Primary Endodontic Lesions.

(b) Primary Endodontic Lesion with Secondary Periodontal Involvement

(c) Primary Periodontal Lesions.

(d) Primary Periodontal Lesion with Secondary Endodontic Involvement (e) "True" Combined Lesions

\section{Primary Endodontic Lesions}

Clinically, this type of lesions is frequently observed with an inflammatory dental pulp. Apical lesion on the necrotic tooth resorbs the alveolar bone around, then a fistula opens into sulcus of the gingiva. ${ }^{7}$ Clinical symptoms of inflammation like pain and tenderness to percussion, mobility, drainage from a sinus tract or swelling cause confusion of primary endodontic lesion with periodontal abscess. The sinus tract results from the necrotic pulp and ends at the attached gingiva can be easily detected by a periapical radiograph taken with a gutta-percha cone and increased probing depth at only involved area although there is no plaque or calculus formation. ${ }^{7,13}$ Furthermore, drainage may occur at the furcation area of the multi-rooted tooth. The possible reason of this situation is the presence of accessory canals related with the furcation area and the furcation appears radiolucent even if there is no bone resorption around roots. The abnormal or negative response to electrical and thermal tests is important to indicate and differentiate the primary endodontic lesions. ${ }^{4,7,13}$

Primary Endodontic Lesions with Secondary Periodontal Involvement

When the treatment of the primary endodontic lesion is delayed, the resorption of the alveolar bone may continue and then, soft and hard tissues are destroyed around the affected tooth. ${ }^{13}$ The presence and accumulation of plaque through gingival sulcus or periodontal pocket with primary endodontic lesion may cause periodontitis. ${ }^{7}$ The tooth with necrotic pulp and plaque accumulation can be diagnosed by probing and radiologically. Radiographic examination may show angular defects associated with endodontic problems. ${ }^{13}$

\section{Primary Periodontal Lesions}

These types of lesions are seen as a result of progressive periodontitis. The periodontal disease begins at the marginal gingiva and may progress to the supportive periodontal tissues if the treatment is delayed.4,7 After the destruction of the hard and soft tissues supporting the tooth, the periodontal abscess may occur. Although it is not certain, in some cases occlusal trauma may contribute to the progression of the periodontal abscesses. Clin- 
ically, increased probing depth around the affected tooth that responds positively to electrical and thermal tests is observed. ${ }^{7}$

Primary Periodontal Lesions with Secondary Endodontic Involvement

The delayed treatment of the outstanding periodontal disease with increased probing depth is the main reason of this type of lesions. However, the effect of periodontal inflammation on the pulp tissue have been controversial. ${ }^{1,14,15}$ The progressive periodontal disease may reach and affect the pulp tissue through the dentinal tubules, lateral and accessory canals or apical foramen. The tooth may be vital in early stage of the disease but with the involvement of the pulp, it responds negatively to electrical and thermal tests. However, radiologically it is difficult to distinguish these lesions from the primary endodontic lesions with secondary periodontal involvement. ${ }^{13}$

\section{True Combined Lesions}

True combined lesions are the conjunction of the pulpal and periodontal diseases that begin independently from each other around the same tooth. There is a necrotic pulp or failed endodontic treatment and extensive bone destruction due to the periodontal disease. ${ }^{13-15}$

\section{Treatment of Endo-Perio Lesions}

The prior treatment choice for the necrotic and non-vital tooth is the non-surgical endodontic treatment even if there is an extensive lesion and periodontal abscesses. Conventional multi-visit endodontic treatment with calcium hydroxide paste, has antibacterial and anti-inflammatory properties, is essential for all the endo-perio lesions except primer periodontal lesions with the vital pulp.,9,13 In primary endodontic lesions, the healing occurs with endodontic treatment alone. In case of secondary periodontal involvement, the periodontal treatment should be considered after the observation of the outcomes of the endodontic treatment. ${ }^{4}$ Studies showed that endodontic treatment stimulates the periodontal tissue healing and the offered time is at least 3 months. ${ }^{14-17}$ The healing effect of endodontic treatment in periodontal tissue can be explained by the pathways of communication between dental pulp and periodontium like accessory canals and dentinal tubules. ${ }^{14}$ However, the complete healing of the primary endodontic lesions with secondary periodontal involvement is achieved with the periodontal treatment. In primary periodontal lesions, if a tooth with an attachment loss down to the apex responds positively to the cold and/or electrical tests, endodontic treatment is contraindicated. ${ }^{1,18}$ In such cases, non-surgical periodontal therapy is the first step of the treatment. ${ }^{3}$ In order to remove the bacterial deposits from the contaminated root surface, scaling and subgingival debridement is necessary. Excessive removal of cementum should be avoided as to prevent unfavourable effect on the pulp by opening the dentinal tubules to bacterial penetration. ${ }^{1}$ Surgical periodontal therapy may be performed to treat osseous defects. The prognosis of primary periodontal lesions is poorer than that of primary endodontic lesions and the treatment choice should be decided due to defect and root morphology. In the case of deep ( $\geq 4 \mathrm{~mm}$ intrabony component) and narrow $\left(\leq 25^{\circ}\right)$ intrabony defects regenerative techniques such as Guided Tissue Regeneration (GTR) or the use of biologically active substances such as Enamel Matrix Derivatives (EMD), Platelet Rich Fibrin (PRF), growth factors and Bone Morphogenetic Proteins (BMP) should be considered..$^{19,20}$ These regenerative periodontal treatment approaches aim to regenerate the lost periodontal tissues destructed during periodontal disease. ${ }^{21}$ However if the defect morphology is shallow $(<4 \mathrm{~mm})$ and wide $\left(>25^{\circ}\right)$, resective surgical treatment options should be taken into consideration. ${ }^{22}$

The treatment of the combined lesions includes both endodontic treatment and periodontal treatment approaches. Although true combined lesions should be first endodontically treated, the conventional endodontic treatment can be unsuccessful due to irregularities of the furcation area and the root canals like isthmuses, lateral, accessory canals. ${ }^{14,19,21}$ Unsatisfactory healing after endodontic treatment may indicate the extraction of the tooth. Also, root resection may be considered for the unhealed periapical lesions in order to maintain the function of the tooth. Thus, the main source of the persisting lesions, the morphological irregularities of the roots and the furcation area are eliminated. Case reports showed that after the root resection, complete healing occurs between 15 to 20 months. ${ }^{19}$ However, the presence of a vertical fracture, tooth with lack of periodontal support and/ or requires advanced restoration methods are contraindicated for this treatment. In addition to these, inadequate patient cooperation or the presence of uncontrolled systemic diseases may be other contraindications to this treatment approach. ${ }^{23}$ From periodontal point view, the prognosis of combined lesions is usually poor or hopeless if severe attachment loss exists. ${ }^{3,24}$ Therefore, hemisection or extraction may also be the treatment of choice due to periodontal reasons. ${ }^{3}$

In order to treat iatrogenic lesions, a seal must be obtained to close the iatrogenic opening. The size, location, periodontal status and the timing of the treatment determine the outcome of the treatment. ${ }^{3}$ Mineral trioxide aggregate (MTA) is widely used for the treatment of iatrogenic lesions to seal the perforation areas because of its proper sealing ability between the internal and external surface of the root besides being a biocompatible and hydrophilic material. ${ }^{25}$ Studies showed that MTA is successfully used for the perforations in the furcation area. ${ }^{26,27}$ Vertical root fractures have hopeless prognosis, therefore should be extracted. ${ }^{28}$ 


\section{CONCLUSIONS}

Endo-perio lesions can be a challenge to clinicians due to its complicated etiology and diagnosis. There is a lack of current documentation concerning the recent treatment protocols of endo-perio lesions. Therefore, this review aimed to highlight the current diagnostic and treatment planning strategies. Correct diagnosis is a prerequisite for a successful treatment and a predictable outcome for such complicated cases. Additionally, further clinical studies and case reports are warranted regarding this issue.

\section{REFERENCES}

1.Zehnder M, Gold SI, Hasselgren G. Pathologic interactions in pulpal and periodontal tissues. J Clin Periodontol 2002; 29: 663-671.

2.Simring $M$, Goldberg M. The pulpal pocket approach: Retrograde periodontitis. J Periodontol 1964; 35: 22-48.

3.Singh P. Endo-Perio Dilemma: A Brief Review. Dent Res J 2011; 8: 39-47.

4.Sunitha RV, Emmadi P, Namasivayam A, Thyegarajan R, Rajaraman V. The Periodontal-Endodontic Continuum: A Review. J Conserv Dent 2008; 11: 54-62.

5.Bergenholtz G, Ricucci D. 'Lesions of Endodontic Origin' Eds: Lang NP, Lidhe J. In: Clinical Periodontology and Implant Dentistry. 5th ed. Blackwell Munksgaard 2008; 504-518.

6.Morfis AS. Vertical root fractures. Oral Surg, Oral Med and Oral Pathol 1990; 69: 631-635.

7.Simon JHS, Glick DH, Frank AL. The relationship of endodontic-periodontic lesions. J Periodontol 1972; 43: 202-208.

8.Amen CR. When is the Condition of the Pulp an Important Consideration in Periodontal Disease? Periodontal Abstr 1967; 15: 7-8.

9.Begin JF. Perio-Endo Considerations: Combined Therapy. R Can Dent Corps Q 1968; 9: 1-5.

10.Oliet S, Pollock S. Classification and Treatment of Endo-Perio Involved Teeth. Bull Phila Cty Dent Soc 1968; 34: 12-16.

11.Simon $P$, Jacobs $P$. The So-Called Combined Periodontal Pulpal Problem. Dent Clinics of NA 1969; 13: 45-52.

12.M Torabinejad, M Trope. "Endodontic and periodontal interrelationships," in Principles and Practice of Endodontics, R. E. Walton and M. Torabinejad, Ed.1996.

13.Kerns DG, Glickman GN. 'Endodontic and Periodontal Interrelationships' Eds: Hargreaves KM, Cohen S, Berman LH. In: Cohen's Pathways of the Pulp. 10th ed. Mosby Elsevier 2011; 655-670.

14.Aksel $H$, Serper A. A case series associated with different kinds of endo-perio lesions. J Clin Exp Dent. 2014; 6(1): 91-5.
15.Seltzer S, Bender IB, Ziontz M. The interrelationship of pulp and periodontal disease. Oral Surg Oral Med Oral Pathol 1963; 16: 1474-1490.

16.Morris ML. Healing of human periodontal tissues following surgical detachment and extirpation of vital pulps. J Periodontol 1960; 31: 23-26.

17.Sanders JJ, Sepe WW, Bowers GM, Koch RW, Williams JE, Lekas JS. Clinical evaluation of freeze-dried bone allografts in periodontal osseous defects. Part III. Composite freeze-dried bone allografts with and without autogenous bone grafts. J Periodontol 1983; 54: 1-8.

18.Petersson K, Söderström C, Kiani-Anaraki M, Levy G. Evaluation of the ability of thermal and electrical tests to register pulp vitality. Endod Dent Traumatol 1999; 15:127-131.

19.Oh SL. Mesiobuccal root resection in endodontic-perodontal combined lesions. Int Endod J 2012; 45: 660669.

20.Karunakar P, Prasanna JS, Jayadev M, Shravani GS. Platelet-rich fibrin, "a faster healing aid" in the treatment of combined lesions: A report of two cases. J Indian Soc Periodontol 2017; 18: 651-655.

21.Sharma R, Hegde V, Siddharth M, Hegde R, Manchanda G, Agarwal P. Endodontic-periodontal microsurgery for combined endodontic-periodontal lesions: An overview. J Conserv Dent 2014;17: 510-516.

22. Oh SL, Fouad AF, Park SH. Treatment Strategy for Guided Tissue Regeneration in Combined Endodontic-Periodontal Lesions: Case Report and Review. J Endod 2009; 35:1331-1336.

23.von Arx T. Apical surgery: A review of current techniques and outcome. Saudi Dent J 2011; 23: 9-15.

24.Adriaens PA, De Boever JA, Loesche WJ. Bacterial invasion in root cementum and radicular dentin of periodontally diseased teeth in humans. A reservoir of periodontopathic bacteria. J Periodontol 1988; 59: 222-230. 25. Torabinejad M, Hong CU, McDonald F, Pitt Ford TR. Physical and chemical properties of a new root-end filling material. J Endod 1995; 21: 349-353.

26. Arens $D E$, Torabinejad M. Repair of furcal perforations with mineral trioxide aggregate: two case reports. Oral Surg Oral Med Oral Pathol Oral Radiol Endod 1996; 82: 84-88.

27.Tsai $Y L$, Lan $\mathrm{WH}$, Jeng JH. Treatment of pulp floor and stripping perforation by mineral trioxide aggregate. J Formos Med Assoc 2006; 105: 522-526.

28.Solomon $\mathrm{C}$, Chalfin $\mathrm{H}$, Kellert M, Weseley P. The endodontic-periodontal lesion: a rational approach to treatment. J Am Dent Assoc 1995; 126: 473-479. 